\title{
Penerapan Metode Pembelajaran Drill terhadap Hasil Belajar Kimia Siswa Kelas X ATPH 1 SMK Negeri 4 Gowa
}

\section{The Implementation of Drill Learning Method to the Chemistry Student's Achievement of the Class X ATPH 1 of SMK Negeri 4 Gowa}

\author{
Ramlah \\ SMK Negeri 4 Gowa
}

\begin{abstract}
ABSTRAK
Penelitian ini adalah Penelitian Tindakan Kelas yang bertujuan untuk menerapkan metode pembelajaran Drill yang mampu meningkatkan hasil belajar siswa. Subjek penelitian ini adalah siswa kelas X ATPH 1 SMK Negeri 4 Gowa yang terdaftar pada tahun pelajaran 2017/2018 dengan jumlah siswa 38 orang. Penelitian ini dilakukan sebanyak 2 siklus, dimana setiap siklus terdiri dari tahap perencanaan, pelaksanaan tindakan, observasi/evaluasi, dan refleksi. Siklus I dilaksanakan sebanyak tiga kali pertemuan proses belajar mengajar dan satu kali pertemuan untuk tes siklus I dan siklus II dilaksanakan sebanyak dua kali pertemuan proses belajar mengajar dan satu kali pertemuan untuk tes siklus II. Peningkatan ketuntasan belajar siswa yaitu $34,21 \%$ pada siklus I menjadi $71,05 \%$ pada siklus II.
\end{abstract}

Kata kunci: Metode Drill, Hasil belajar

\begin{abstract}
This research is a Class Action Research which aims to apply the Drill learning method which is able to improve student learning outcomes. The subjects of this study were students of class X ATPH 1 of SMK Negeri 4 Gowa registered in the 2017/2018 school year with a total of 38 students. This research was conducted in 2 cycles, where each cycle consisted of planning, action, observation / evaluation, and reflection stages. Cycle I was held three times a meeting of the teaching and learning process and one meeting for the first cycle test and the second cycle was carried out two times the teaching and learning process meetings and one meeting for the second cycle test. The increase in student learning completeness is $34.21 \%$ in the first cycle to $71.05 \%$ in the second cycle.
\end{abstract}

Keywords: Drill Method, Student's Achievement 


\section{PENDAHULUAN}

Salah satu komponen yang sangat penting dalam proses belajar mengajar adalah metode mengajar. Pencarian metode pembelajaran yang efektif yang telah banyak diperbincangkan dalam dunia pendidikan karena sangat diperlukan, terutama dalam pemilihan metode pembelajaran yang dapat mengaktifkan siswa. Di dalam kenyataan, cara atau metode mengajar yang digunakan oleh guru untuk menyampaikan informasi atau pesan kepada siswa berbeda dengan cara yang ditempuh untuk memantapkan siswa dalam menguasai pengetahuan, keterampilan serta sikap.

Pemilihan metode mengajar harus memperhatikan beberapa faktor antara lain tujuan yang ingin dicapai siswa, situasi, dan fasilitas belajar mengajar yang diperlukan dalam pembelajaran tersebut. Apabila guru dalam proses belajar mengajar menggunakan metode yang tepat serta memperhatikan situasi siswa dan lingkungan belajar yang mendukung, juga ditunjang dengan fasilitas yang memadai, maka akan meningkatkan hasil belajar siswa (Suryosubroto, 2002).

SMK Negeri 4 Gowa merupakan salah satu sekolah yang telah menerapkan sistem pembelajaran K 13 dengan standar ketuntasan untuk mata pelajaran kimia adalah $75 \%$. Berdasarkan hasil observasi dan wawancara terhadap guru mata pelajaran kimia, diperoleh keterangan bahwa pada tahun ajaran 2015/2016 ketuntasan untuk materi struktur atom dan sistem periodik hanya mencapai
$56 \%$ dan setelah dilakukan remedial, ketuntasannya mencapai 63\%. Pada materi struktur atom dan sistem periodik siswa membutuhkan kecakapan mental, misalnya: menghafal, menjumlah, mengkalikan dan membagi. Selain itu, siswa juga sudah harus mampu mengintegrasikannya dengan meterimateri lain khususnya tentang stoikimetri.

Salah satu cara yang perlu dilakukan untuk menanggulangi rendahnya hasil belajar siswa tersebut adalah menggunakan metode yang sesuai dengan materi yang akan diajarkan dan lebih menjadikan siswa sebagai pusat pembelajaran. Salah satu metode pembelajaran yang dipandang mampu mengaktifkan dan meningkatkan hasil belajar siswa adalah metode Drill atau latihan.

Penggunaan metode ini cukup luas, seperti latihan pemecahan soal, kesenian, keterampilan mengarang, bekerja dan sebagainya. Pada umumnya metode ini berisi rangkaian kegiatan mengulang suatu perbuatan sampai perbuatan tersebut dikuasai. Secara umum langkah-langkah pembelajaran Drill (latihan) terstruktur adalah sebagai berikut (Halia, 2008).

1. Guru menjelaskan tujuan pembelajaran yang ingin dicapai.

2. Apersepsi atau motivasi.

3. Menjelaskan materi dengan singkat disertai dengan contoh soal, kemudian memberikan kesempatan kepada siswa untuk bertanya.

4. Memberikan soal latihan secara berulang, pemberian latihan dilakukan secara terstruktur. 
5. Guru mengawasi dan memberikan bimbingan kepada siswa yang belum mengerti.

6. Mempersilahkan beberapa siswa untuk tampil mengerjakan soal latihan setiap selesai mengerjakan satu soal kemudian dibahas bersama.

Metode Drill dipandang mampu meningkatkan kemampuan siswa. Semakin sering suatu perilaku dilatih atau digunakan maka semakin mantap eksistensi perilaku tersebut (Muhibbin Syah, 2004).

Sehubungan dengan hal tersebut di atas, maka tujuan penelitian ini adalah untuk mengetahui bagaimana cara menerapkan langkahlangkah metode pembelajaran Drill sehingga dapat meningkatkan hasil belajar kimia siswa kelas X ATPH 1 SMK Negeri 4 Gowa.

\section{METODE PENELITIAN}

Penelitian ini merupakan penelitian tindakan kelas (PTK) dengan tahapan-tahapan pelaksanaan yang meliputi perencanaan, pelaksanaan tindakan, observasi, evaluasi, serta refleksi yang bertujuan untuk meningkatkan hasil belajar siswa setelah dilakukan perbaikan terhadap proses pembelajaran secara terus menerus. Penelitian tindakan kelas ini telah dilaksanakan di SMK Negeri 4 Gowa. Subjek penelitian adalah siswa kelas X ATPH I tahun pelajaran 2017/2018 yang berjumlah 38 orang. Dalam pelaksanaannya, penelitian ini meliputi dua siklus dimana siklus I dan siklus II masingmasing terdiri atas tiga kali pertemuan (6 jam pelajaran) serta dua kali pertemuan untuk tes hasil belajar di akhir setiap siklus. Data nilai hasil belajar didapatkan menggunakan persamaan.

Nilai Siswa $=\frac{\text { Skor Total }}{\text { Skor Maksimal }} \times 100$

Data yang dihasilkan dari penelitian ini dianalisis melalui analisis kualitatif dan analisis deskriptif. Data hasil observasi selama proses pelaksanaan pembelajaran berlangsung dianalisis secara kualitatif, sedangkan skor rata-rata dari hasil tes tiap siklus dianalisis dengan menggunakan statistik deskriptif, kemudian hasilnya dikelompokan berdasarkan kriteria ketuntasan yang ditetapkan oleh sekolah. Kriteria ketuntasan belajar klasikal siswa dalam kelas disajikan pada Tabel 1. Indikator keberhasilan dalam penelitian ini adalah meningkatnya hasil belajar siswa atau ketuntasan belajar siswa dari data sebelumnya.

Tabel 1. Kriteria Ketuntasan Belajar Siswa SMK Negeri 4 Gowa

\begin{tabular}{cc}
\hline Nilai & Kategori \\
\hline $75-100$ & Tuntas \\
\hline $0-74$ & Tidak Tuntas \\
\hline
\end{tabular}

\section{HASIL DAN PEMBAHASAN}

Data hasil belajar kimia pada siklus I diperoleh melalui pemberian tes hasil belajar kimia. Data hasil tes tersebut dianalisis secara deskriptif dan menunjukkan bahwa skor tertinggi yang diperoleh pada siklus I yaitu 80 dan skor terendah yaitu 35 dengan skor rata-rata siswa dalam kelas adalah 54,39 dengan jumlah 38 siswa. Hal ini menujukkan bahwa hasil belajar siswa 
pada siklus I masih tergolong rendah. Nilai ketuntasan belajar siswa berdasarkan daya serap siswa terhadap materi pelajaran yang dikelompokkan ke dalam kategori tuntas dan tidak tuntas, maka diperoleh distribusi, frekuensi dan persentase belajar kimia yang ditunjukkan pada Tabel 2 .

Tabel 2. Deskriptif Ketuntasan Belajar Siswa pada Siklus I

\begin{tabular}{lccc}
\hline \multicolumn{1}{c}{ Kategori } & Skor & Frekuensi & Persentase (\%) \\
\hline Tidak Tuntas & $0-74$ & 25 & 65,79 \\
\hline Tuntas & $75-100$ & 13 & 34,21 \\
\hline \multicolumn{2}{c}{ Jumlah } & 38 & 100 \\
\hline
\end{tabular}

Hasil di atas menunjukkan bahwa pada siklus I, hasil belajar kimia siswa kelas X ATPH 1 SMK Negeri 4 Gowa belum berada pada kategori tuntas sebab banyaknya siswa yang memperoleh nilai $\geq 75$ hanya 13 orang yang apabila dipresentasekan memiliki nilai sebesar $34,21 \%$.

Hasil analisis deskriptif tes hasil belajar kimia siswa pada siklus II memperlihatkan bahwa terjadi peningkatan hasil belajar kimia siswa. Hal itu dapat dilihat dari meningkatnya skor yang diperoleh siswa pada siklus II dimana skor tertinggi yang diperoleh siswa yaitu 85 dan untuk skor terendah yaitu 40. Selain itu, nilai rata-rata kelas untuk siklus II juga mengalami peningkatan dari 54,39 menjadi 61,05.
Ketuntasan belajar siswa berdasarkan daya serap siswa terhadap materi pelajaran yang dikelompokkan ke dalam kategori tuntas dan tidak tuntas, maka diperoleh distribusi, frekuensi dan persentase belajar kimia pada Tabel 3.

Data pada Tabel 3 menunjukkan bahwa pada siklus II, hasil belajar kimia siswa kelas $\mathrm{X}$ ATPH 1 SMK Negeri 4 Gowa sudah berada pada kategori tuntas sesuai dengan standar ketuntasan minimal yang ditetapkan oleh sekolah yaitu $65 \%$, dimana banyaknya siswa yang memperoleh skor $\geq 65$ yaitu 27 orang yang apabila dipersentasekan memiliki nilai $71,05 \%$.

Tabel 3. Deskriptif Ketuntasan Belajar Siswa pada Siklus II

\begin{tabular}{|c|c|c|c|}
\hline Kategori & Skor & Frekuensi & Persentase (\%) \\
\hline Tidak Tuntas & $0-74$ & 11 & 28,95 \\
\hline Tuntas & $75-100$ & 27 & 71,05 \\
\hline \multicolumn{2}{|c|}{ Jumlah } & 38 & 100 \\
\hline
\end{tabular}


Berdasarkan indikator keberhasilan yang ditetapkan dalam penelitian ini, maka dapat dikatakan bahwa penelitian pada siklus I ini belum berhasil. Oleh karena itu, penelitian ini diteruskan ke siklus II dengan meninjau kembali (merefleksi) hal-hal yang harus dibenahi, diperbaiki dan ditingkatkan sehingga hasil belajar dan keaktifan siswa bisa lebih meningkat.

Fokus refleksi yang dilakukan adalah bagaimana mengaktifkan siswa agar lebih memperhatikan pelajaran, lebih berani bertanya atau memberikan tanggapan serta aktif dalam mengerjakan latihan-latihan yang diberikan. Oleh sebab itu, perbaikan yang dilaksanakan pada siklus II lebih ditekankan pada pengelolaan kelas agar proses belajar mengajar dapat berjalan lancar dan lebih aktif. Perbaikan langkah pada siklus II ini meliputi pemberian motivasi, dorongan ataupun penghargaan, sehingga siswa merasa termotivasi dan lebih berani untuk bertanya, menanggapi atau menjawab pertanyaan. Perbaikan langkah yang lainnya adalah membagi siswa dalam kelompok kecil yang beranggotakan 3 orang secara heterogen sehingga siswa yang merasa ragu atau kurang percaya diri untuk bertanya langsung kepada guru dapat bertanya kepada teman dalam kelompoknya dan menunjuk langsung kepada siswa untuk menjawab atau menanggapi pertanyaan serta untuk mengerjakan latihan di papan tulis, sehingga siswa akan selalu berusaha mempersiapkan diri.
Perbandingan hasil belajar pada siklus I dan siklus II dapat dilihat pada Tabel 4.

Tabel 4. Perbandingan Hasil Belajar Siswa Pada Siklus I dan Siklus II

\begin{tabular}{llcc}
\hline No & Kategori & $\begin{array}{c}\text { Siklus } \\
\text { I }(\%)\end{array}$ & $\begin{array}{c}\text { Siklus } \\
\text { II (\%) }\end{array}$ \\
\hline 1 & $\begin{array}{l}\text { Skor } \\
\text { tertinggi }\end{array}$ & 80 & 85 \\
\hline 2 & $\begin{array}{l}\text { Skor } \\
\text { terendah }\end{array}$ & 35 & 40 \\
\hline 3 & $\begin{array}{l}\text { Skor rata- } \\
\text { rata }\end{array}$ & 54,39 & 61,50 \\
\hline 4 & $\begin{array}{l}\text { Tuntas } \\
\text { (skor } \geq 75)\end{array}$ & 34,21 & 71,05 \\
\hline 5 & $\begin{array}{l}\text { Tidak } \\
\text { tuntas } \\
\text { (skor }<75)\end{array}$ & 65,79 & 28,95 \\
\hline
\end{tabular}

Hasil penelitian ini menunjukkan bahwa pada siklus I, skor tertinggi yang diperoleh oleh siswa yaitu 80 dan skor terendah adalah 35 dan setelah nilai hasil belajar siswa kelas X ATPH 1 SMK Negeri 4 Gowa dirata-ratakan, maka nilai yang diperoleh adalah 54,39. Mengacu kepada standar ketuntasan belajar yang ditetapkan oleh sekolah, maka banyaknya siswa yang masuk kategori tuntas hanya sebanyak 13 orang, sedangkan sisanya 25 orang berada pada kategori tidak tuntas, ini berarti bahwa ketuntasan yang dicapai hanya 34,21\%. Kebanyakan siswa pada siklus I, masih kesulitan dalam menentukan molalitas, dimana siswa yang mampu menyelesaikan tes yang berkaitan dengan penentuan molalitas hanya sebanyak 13 orang atau sekitar $34,21 \%$. 
Dari hasil analisis deskriptif siklus II memperlihatkan bahwa terjadi peningkatan hasil belajar kimia. Hal ini dapat dilihat dari meningkatnya skor yang diperoleh siswa setelah dilakukan tes siklus II dimana skor tertinggi adalah 85 dan skor terendah adalah 40 dan setelah dirata-ratakan menjadi 61,50 (rata-rata kelas). Meskipun peningkatan rata-rata skor hasil belajar siswa tidaklah terlalu signifikan, yaitu dari 54,39 menjadi 61,50, namun nilai yang mencapai standar ketuntasan hampir merata pada siswa sehingga banyak siswa yang masuk pada kategori tuntas. Mengacu pada standar ketuntasan belajar siswa yang ditetapkan oleh sekolah, dapat dilihat bahwa sebanyak 27 siswa berada pada kategori tuntas dengan persentase $71,05 \%$. Sedangkan jumlah siswa yang masih berada pada kategori tidak tuntas sebanyak 11 siswa yang jika dipersentasekan sebesar 28,95\%.

Usaha meningkatkan aktivitas dan hasil belajar siswa merupakan hal yang tidaklah mudah. Salah satu cara untuk meningkatkan aktivitas dan hasil belajar siswa adalah dengan memilih metode yang tepat, sedangkan penerapan metode pembelajaran yang tidak tepat dapat menurunkan motivasi dan minat belajar siswa sehingga tujuan pembelajaran tidak tercapai secara optimal.

Berdasarkan hasil penelitian dan uraian di atas, diperoleh informasi bahwa penerapan pembelajaran Drill dapat meningkatkan hasil belajar siswa dengan menggunakan langkah-langkah sebagai berikut:

1. Guru menyampaikan tujuan pembelajaran yang ingin dicapai dan metode yang akan digunakan (metode Drill).

2. Guru memberikan apersepsi kepada siswa.

3. Guru membentuk kelompok yang beranggotakan 3 orang secara heterogen.

4. Guru membahas materi pokok dengan singkat disertai dengan contoh soal dan memberikan kesempatan kepada siswa untuk bertanya.

5. Guru memberikan soal latihan berulang kali (pemberian latihan secara terstruktur), kemudian mengerjakan latihan secara berkelompok,

6. Guru tetap mengawasi dan memberikan bimbingan jika terdapat kesulitan.

7. Guru mengevalusi hasil belajar dengan cara menunjuk beberapa orang untuk mempresentasekan hasil pekerjaan kelompoknya setiap selesai mengerjakan satu soal.

8. Guru memberikan penghargaan kepada siswa/kelompok yang mampu menyelesaikan latihan dengan benar.

\section{KESIMPULAN DAN SARAN}

\section{A. Kesimpulan}

Berdasarkan hasil analisis data dan pembahasan, maka dapat ditarik kesimpulan bahwa metode pembelajaran Drill dapat meningkatkan hasil belajar siswa kelas $\mathrm{X}$ ATPH 1 SMK Negeri 4 Gowa dengan peningkatan ketuntasan belajar siswa yaitu $34,21 \%$ pada siklus I menjadi $71,05 \%$ pada siklus II. 


\section{B. Saran}

Metode pembelajaran Drill dapat menjadi inovasi pembelajaran guna meningkatkan motivasi mahasiswa dalam belajar terlebih meningkatkan hasil belajar. Dengan demikian, diharapkan dapat mencoba metode pembelajaran Drill pada materi kimia yang lain.

\section{DAFTAR PUSTAKA}

Halia, 2008, Peningkatan Hasil Belajar Kimia Melalui Penerapan Metode Latihan Berstruktur pada Siswa Kelas XI $I P A_{2}$ SMA N 1 Barru, Jurnal
Ilmu Kependidikan, Vol. 5 No. 1, Mei 2008.

Muhibbin Syah., 2004, Psikologi dengan Pendekatan Baru (edisi revisi), PT Remaja Rosda Karya, Bandung.

Suryosubroto, B., 2002, Proses Belajar Mengajar di Sekolah, Rineka Cipta, Jakarta. 